\title{
THE LEGAL PROTECTION FOR A GOOD FAITH BUYER UNDER A COURT DECISION
}

\author{
Muhammad Faisal ${ }^{*}$ \\ Law Office H. Ayub, S.H., M.H. \& Associates, Medan \\ Jalan Prof. H. M. Yamin, S.H. No. 8-Q, Medan, Sumatera Utara
}

\begin{abstract}
There are various principles given in Indonesian Civil Code (KUHPerdata) and HIR/RBg in providing legal protection on good faith purchaser, but all of these principles eventually dropped their pedestal on a judge's verdict to decide whether or not the intention of the buyer is based on a good faith purchaser. There are also many factors that can influence the decision of a judge that can lead to different conceptions of the protection provided. In addition, the rapid development of the present law requires judges to review the general principles of law and also applying existing law theories in the making of their verdict.
\end{abstract}

Keywords: legal protection, good faith purchaser, judge verdict.

\section{Intisari}

Permasalahan perlindungan hukum pembeli beritikad baik merupakan masalah yang cukup mendasar dalam hukum kita. Terdapat berbagai prinsip yang diberikan dalam KUHPerdata maupun HIR/RBg dalam mengupayakan perlindungan hukum pembeli beritikad baik, akan tetapi upaya-upaya tersebut pada akhirnya menjatuhkan tumpuannya pada putusan hakim untuk menilai beritikad baik atau tidaknya seseorang. Di sisi lain, terdapat banyak faktor yang mempengaruhi putusan seorang hakim sehingga apabila dikaitkan dengan itikad baik, dapat menimbulkan konsepsi yang berbeda-beda terhadap perlindungan yang diberikan. Selain itu, pesatnya perkembangan hukum sekarang ini mewajibkan hakim-hakim untuk mempelajari kembali asas-asas hukum serta menerapkan teori-teori hukum yang ada dalam membuat putusannya.

Kata Kunci: perlindungan hukum, pembeli beritikad baik, putusan hakim.

\section{Pokok Muatan}

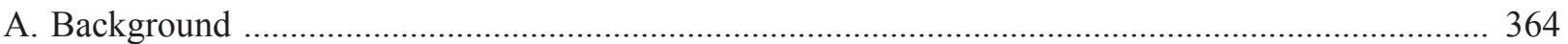

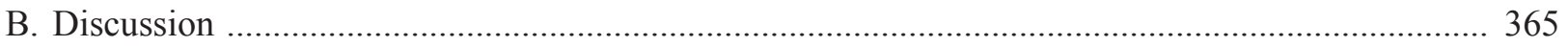

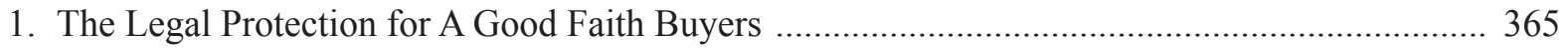

2. Legal Theory Related to the Court Decision .......................................................................... 366

3. The Existence of Good Faith in a Court Decision ...................................................................... 369

4. The Legal Protection for a Good Faith Buyer in a Court Decision ............................................ 370

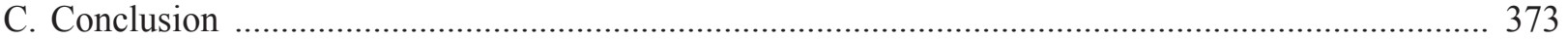




\section{A. Background}

The meaning of good faith can be defined as honest or honesty. ${ }^{1}$ It does not clearly explain what exactly good faith is under the Indonesian Civil Code (KUHPerdata). Good faith is related to the norm of society, meaning that it is related to the legal awareness of society that needs guidance and regulation. ${ }^{2}$ The regulation related with good faith can be found under the Indonesian Civil Code. The regulation of good with regards to possession (bezit) can be found under the Article 531, 532, 534, 548, 549, 584, 1965 and 1966.

Regarding the legal protection for the good faith buyers, set forth under the Article 1977 point (1) of Indonesian Civil Code in which such article protects the movable goods buyer who has good faith. Article 1977 (1) of Indonesian Civil Code said that, "Towards the movable goods that is not in the form of interest, or debt and it should not be paid to the carrier so that for those who has a control over such goods is regarded as the owner". Unlike the movable goods, it becomes questionable on how does it regulate the immovable goods in which the Indonesian Civil Code does not govern the immovable goods. According to Prof. R. Subekti, S.H., he mentioned that the Article 1977 (1) is imposed to all kind of goods; thus, it is not necessary to mention the immovable goods to be stated as if an agreement is concluded before an official, hence, the parties can be considered as having good faith. ${ }^{3}$ Based on the aforementioned, it is recognized that the good faith buyers is obliged to acquire legal protection.

A good faith is closely related to the right of ownership issue. As it is laid down under the Article 584 Indonesian Civil Code, it is stated that "The Right of ownership over goods cannot be possessed by any other way instead of by the right of ownership, due to adhesion; due to expiration; due to inheritance, either based on an Act, or based on a testament and due to appointment or handover based on certain civil action for transferring the right of ownership, conducted by a person who is entitled to do anything towards such goods". Moreover, taking a look at Article 531 of Indonesian Civil Code, it is stipulated "Such position is in good faith manner, whenever the goods holder obtain such goods by way of acquiring the right of ownership, in the condition that he does not know the defects of such goods contained therein". From such articles, it can be found the position of the good faith possessor obtained from the procedure of ownership.

Article 530 of Indonesian Civil Code mentioned that "Such position can be possibly good faith, or bad faith". Regarding bad faith is set forth under the Article 532 of Indonesian Civil Code saying that "it is bad faith whenever the possessor aware, that he is not the owner of such goods". In addition, in Article 533 of Indonesian Civil Code mentioned, "Good faith is always considered exist in every person of the position holder; for those who allege for a person having bad faith, he must prove such allegation". Thus, from the Article aforesaid, it can be found that the problem of good faith occurred when other party put that issue into the dispute in a court. By the mentioned articles, it is recognized that the judges is at the end declared who has good faith and who does have any good faith in their decisions.

In determining person's good faith, the judge should understand regarding the existence of such good faith either in practice or in principles under the civil law. Besides, there are some factors that shall influence a judge in decision-making process, so that, it can cause a different conception in determining good faith or no good faith of buyers, in which at the end, it may also cause different conceptions in facilitating the legal protection for good faith buyers.

The issue of good faith buyers is a topic that needs to be researched since it is closely related to the court verdict and these are two things that is

Djaja S. Meliala, 1987, Masalah Itikad Baik dalam KUHPerdata, Bina Cipta, Bandung, p. 1. 
often connected each other, in which the existence of its connection has made the national law and regulation ambiguous, so that, it is needed to build a meeting mind that can be the guidance of the legal certainty and justice in our national law. Based on the discussion above, the author tried to discuss regarding the legal protection for a good faith buyer facilitated by court decision, the legal problem will be discussed in this paper is regarding: what kind of legal protection shall be given to a good faith buyer by way of court decision so it does not make any disparity towards the given protection with taking into account the applicable legal theories.

\section{B. Discussion}

\section{The Legal Protection for A Good Faith Buyers}

In the Black's Law Dictionary, good faith is defined as:

A state of mind consisting in (1) honesty in belief or purposes. (2) faithfulness to one's duty or obligation, (3) observance of reasonable commercial standards of fair dealing in a given trade or business, or (4) absence of intent to defraud or to seek unconscionable advantage. ${ }^{4}$

Under Article 548 of Indonesian Civil Code mentioning "every possession with good faith, shall give the following rights to the possessor on the property possesses:

a. that he, until such time the property is reclaimed before the judge, temporarily must be deemed as the owner of the property;

b. that he, by way of expiration, can obtain the ownership on such property;

c. that he, until such time of reclaiming the property before the judge, shall be entitled to enjoy any product of it;

d. that he must be defended in his possession, if he is being interfered in his possession, or to be reinstated to such possession, if he lost his possession.

Besides, Article 1977 (1) of Indonesian Civil Code stated that: "For the movable goods which is not in the form of either interest or debt that should not be paid to the carrier, thus for those who possess it shall be regarded as its owner". Based on Prof. R. Subekti, the Article 1977 of Indonesian Civil Code is applied to the immovable goods as well in which in the condition the agreement is concluded before an official.

Theoretically, a good faith buyer will be protected based on its good faith position that is in accordance with the Articles under the Indonesian Civil Code. However, concerning the good faith buyer as a third party in the dispute of ownership, there is another type of protection.

According to Article 195 subparagraph (6) of HIR (Herzien Inlandsch Reglement) (Article 258 subparagraph (6) of R.Bg (Rechtsreglement Buitengewesten), Article 378 of Rv (Reglement of de Rechtsvordering)), it is possible for third party or the opposite party (a good faith buyer) submits rebuttal (Derden Verzet) against the final decision. ${ }^{5}$ Concerning the seizure upon the court decision, the third party can submit a rebuttal against such seizure if apparently the seized goods belong to him and he can prove his ownership right. ${ }^{6}$ The rebuttal will be examined by the district court first in order to be decided, after hearing both parties concerned. The rebuttal process does not hinder the auction over the seized goods, unless if the chairman of district court orders to suspend the auction until the final court decision, as stipulated under the Article 196 subparagraph (6), Article 207, Article 208, Article 206 subparagraph (6), Article 226 and Article 227 of HIR and Article 228 of R.Bg. Furthermore, the rebuttal against the dispute which has been settled under the court decision cannot be used for countering eksekutorial seizure. ${ }^{7}$

Bryan A. Garner, 2009, Black's Law Dictionary, Thompson Reuters, USA.

M. Yahya Harahap, 1993, Perlawanan terhadap Eksekusi Grose Akta Serta Putusan Pengadilan dan Arbitrase dan Standar Hukum Eksekusi, Citra Aditya Bakti, Bandung, p. 323.

Abdulkadir Muhammad, 1990, Hukum Acara Perdata Indonesia, Citra Aditya Bakti, Bandung, pp. 228-229.

Sudikno Mertokusumo, 1998, Hukum Acara Perdata Indonesia, Liberty, Yogyakarta, p. 250. 
HIR does not regulate regarding the third party rebuttal against the conservatoir seizure and revindicatoir seizure, in which the rebuttal against the real execution does not regulate as well, if it is so, such rebuttal can still be submitted. ${ }^{8}$ In practice, according to the precedent of Supreme Court on November 31 st 1962 Number 306 K/Sip/1962 in the case of CV. Sallas dkk. V. PT. Indonesian Far Eastern Pasific Line, it is declared that eventhough the rebuttal concerning conservatoir seizure does not regulate spesifically under HIR, based on precedent, the rebuttal is submitted by the third party as the owner of the seized goods can be accepted, in conservatoir seizure as well, although it is not legalized yet (van waarde verklaard). ${ }^{9}$

Article 380 of Rv provides authority for the court to postpone the execution if there is a rebuttal. However, the rebuttal cannot be generelized postponing the execution. The postponing process is an exceptional. The criteria of such exceptional postponing are as follows: ${ }^{10}$

a. the goods that will be executed is belong to opposing party;

b. the goods that will be executed has been mortgaged to the opposing party.

For the seized goods that has become in the possession of third party, based on the decision of uitvoerbaar bij voorraad, if the defendant is willing the objects to be restored to him physically or in natura, the defendant has to follow the process of claim in the court. ${ }^{11}$ The process of restoration against the third party, is laid down under one of the Supreme Court decision Number 323K/ Sip//1968 that "the buyer in executie auction has to be protected, if the executie bij voorraad happened, whereas the court decision is then annulled, the only way to restore the condition is file a claim against the mortgaged goods given by the executant in the time when submitting the executie claim".
The essential thing under such decision is that the restoration of the goods possessed by the third party must be declared: cannot be executed or nonexecutable, and its execution has to start by filing the claim first. ${ }^{12}$

As in auction, the object of auction possessed by the buyer from the winner of auction based on the court decision cannot be directly executed. An object that is controlled by the buyer from the winner of auction can be executed by way of filing a claim to the court first. Under the court trial, the buyer has the chance to protect his position based on a good faith buyer principle.

Besides for such protection, there is another protection: a legal protection. There are so many cases that can be examples of legal protection process, for instance in the Supreme Court Decision Number $556 / \mathrm{PK} / \mathrm{Pdt} / 2012$. In the merit of the case, there was an execution that is detrimental to third party as a good faith buyer. The execution is conducted without any claim first, so that it triggered evident losses for the third party without having a chance to protect his rights before the court. Based on that case, the third party filed a request to the Supreme Court, in which the Supreme Court said: The Supreme Court enacted the provision for suspending such execution and declared the undertaken execution has no final legal binding so that it provides legal certainty for a good faith buyer.

According to the aforementioned, it is clear that the protection for the good faith buyer is closely related to the court that decides whether it is a good faith or not, so the court decision becomes the determinant. Therefore, the judges should take into account the principles of civil law and the legal theories that is applicable in passing a decision.

\section{Legal Theory Related to the Court Decision}

The court decision is a scholarly process in which the judges as the main core of the decision.

Supomo, 1985, Hukum Acara Perdata Pengadilan Negeri, Fasco, Jakarta, p. 195.

Mahkamah Agung RI, 2008, Pedoman Teknis Administrasi dan Teknis Peradilan Perdata Umum dan Perdata Khusus, Mahkamah Agung RI, Jakarta, pp. 101-103

M. Yahya Harahap, Op.cit., pp. 324-325.

11 M. Yahya Harahap, 2007, Hukum Acara Perdata: tentang Gugatan, Persidangan, Penyitaan, Pembuktian dan Putusan Pengadilan, Sinar Grafika, Jakarta, p. 908.

12 Ibid., p. 909. 
The judges hold the central position in making the decision over the dispute. The legal implementation in court decision is related to certain systematically framework, so that the doctrine or legal theories hold the important factor in leading the judges making the decision and it can accommodate the legal purpose i.e. justice, legal certainty and the benefits of law. ${ }^{13}$

According to Aristoteles, the law became the guidance of human beings in the rational morality values, so it has to be fair in which the justice is similar to public justice. The justice is marked by the good relationship from one and another with the similarity. The 'social-ethical' feeling as the basis of its formulation, justice according to Aristoteles is depending on three principle of natural law, in which considered as the main principle: Honeste Vivere, Alterum non laedere, Sunm quique tribuere (live honorably, not disturbing each other, and giving his parts to everyone). ${ }^{14}$

Justice constitutes one of the aims of every legal systems and it is the most important purpose. There are other purposes that become the basis of law, that is legal certainty, advantage and order. Besides, justice can be seen as a value. There are four values constitutes as main basis: ${ }^{15}$ justice; truth; law; and morality. However, from such four values, based on Plato, justice is highest value. According to Plato, "Justice is the supreme virtue which harmonize all other virtues" ${ }^{16}$ In every doctrine of law, it seems that it focus on the justice aspect in passing the decision.

Sudikno Mertokusumo stated that in every ideal decision, it must be contained 3 (three) elements: legal certainty (Rechtssicherheit), the advantage (Zweckmassigkeit), and justice (Gerech- tigkeit). However, in practice, it is rare to find the decision that contains such three elements proportionally. If it cannot be proportional, at least, the three elements must be found in a decision. ${ }^{17} \mathrm{In}$ a case, the defeated party, considered the decision does not exist, since he or she feel aggrieved. This is because the human nature of looking the truth of themselves, that is not fair for A does not necessarily mean it is fair for $B$ as well. It is impossible for judges to satisfy both parties at once since the interest of defendants and plaintiffs is sometimes and always contradictory. Thus, Sudikno Mertokusumo stated that justice is a value towards the action or behavior of a person to the other person, and commonly it is valued from the person who is being imposed by the action. Hence, the meaning of fair decision is that the concerned parties recognize the fairness or justice, although, the opposing party does not think that it is fair, but the society has to recognize as it is fair. ${ }^{18}$

In a case, the legal certainty is sometimes in contradiction with justice. The legal certainty is performed under the condition where it feels like unfair (lex dura sed tamen scripta; law is cruel but it said so). Although, there is a conflict between the legal certainty, justice, and advantage under a decision, then justice must be prioritized. ${ }^{19}$

Here is the relevant theories with court decision, either the specific theories or general theories in discussing about the implementation of law in court decision: ${ }^{20}$

1. Pure Legal Theory;

2. Analysis Theory;

3. Historical Theory;

4. $\quad$ Law as the Interest Balance Theory;

5. Incidental Condition Theory;

6. Realism Law Theory;

\footnotetext{
13 M. Natsir Asnawi, 2014, Hermeneutika Putusan Hakim: Pendekatan Multidisipliner dalam Memahami Putusan Peradilan Perdata, UII Press, Yogyakarta, p. 50.

Ibid., p. 42.

Wildan Suyuthi Musthofa, 2013, Kode Etik Hakim, Kencana, Jakarta, p. 101.

Munir Fuady, 2006, Aliran Kritis Paradigma Ketidakberdayaan Hukum, Citra Aditya Bakti, Bandung, p. 52.

Sudikno Mertokusumo, 2014, Penemuan Hukum: Sebuah Pengantar, Cahaya Atma Pustaka, Jakarta, p. 118.

Ibid., p. 117.

Ibid., p. 118

M. Natsir Asnawi, Op.cit., pp. 50-69.
} 
7. Contextual Interpretation Theory;

8. Justice Theory;

9. Mashlahah Mursalah Theory; and

10. Progressive Law Theory.

In this paper, the main focus is on the realism law theory. The principle of epikeia by Aristoteles or the Plato's equity principal, which has its function to accommodate the distance between certainty and justice that is considered not in line with legalism. Legalism is way of thinking based on the regulation, principals or objective norm that is applicable in any situation and condition. ${ }^{21}$ The law changes into a long list with regards to on what is allowed to do and what is prohibited. It is not possible not to do it perfectly, but there is a threaten access, that is a rigid legalism which can cause the law does not any longer to serve people, but the other way way around: the people serve the law. ${ }^{22}$

For countering such issue, the realism law adherents try to break its rigidness. He is Oliver Wendell Holmes and Jerome Frank, who later on declared legal theory as the judges behavior. ${ }^{23} \mathrm{In}$ brief, the idea of Oliver Wendell Holmes regarding the law as a formalization opposing movement from the Acts as follows: ${ }^{24}$

1. Law constitutes decision of the judge or court decision; ${ }^{25}$

2. The idea of Oliver Wendell Holmes regarding the law started from his idea that law is the same with experience, and so is the logic, ${ }^{26}$

3. Law is the patterns of behavior, where such behavior is determined by three factors, as an issue influencing the court decision, is a legal doctrine that is being concreted by the judge with the interpretation method and construction, morality of the judges and social interest. ${ }^{27}$

4. The essential issue from law is the development of legal science in fact examination and the life of the law has been, not logic, but experience. ${ }^{28}$

Based on Holmes, the truth is not under the Act but in real life. Holmes as a judge often face the 'truth' seems demanding for certainty on which one is 'better' and certain context. One of them, it is the truth of regulation, or other truths that maybe higher than the regulation. In this sense, a judge bets its sensibility and wisdom. He must 'win' the truth that he thinks better, although with the risk of defeating the official provision. ${ }^{29}$

Along with Holmes, Jerome Frank has the same opinion. Based on Frank, a judge is able to make other decision out of the formal regulation, from the main priority; it is better to put the legal basis according to the formal regulation. Indeed, the applicable legal doctrines influence the decision of a judge. However, it is only one of the consideration elements. Besides, political prejudice, economics and morality also determine the decision of judges. In addition, the sympathy and personal antipathy take a role in determining such decision. ${ }^{30}$

Benjamin Cordozo appeared to justify the statement of Jerome Frank, however, according to Cordozo, the space of freedom and psychological aspects that influence the judges in decision-making process, it does not necessarily mean that the judge may forget in normative aspects from law, which is to serve the public interest for justice. The dignity of a judge, according to Cordozo, is under his loyalty to uphold its purpose of law. Therefore, the court decision is not allowed to develop freely without any limitation in which the activities of judges is bound

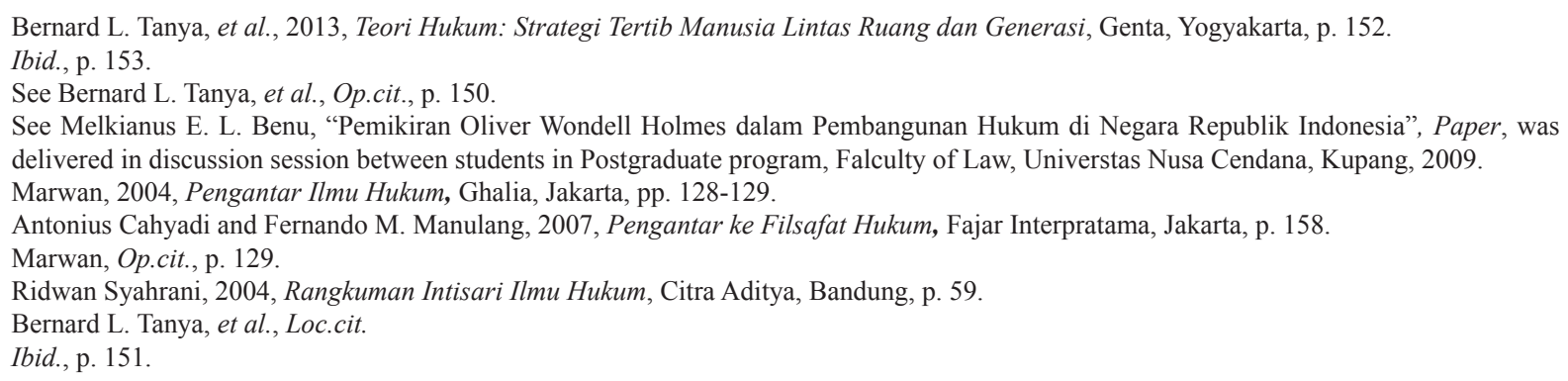


under the public interest as the core of justice. ${ }^{31}$

Related to the realism law theory, it can be seen that the judicial power is completely needed in providing solution with regards to dispute of a good faith buyer protected by the law. The sensibility and wisdom of a judge is needed to decide the dispute settlement, however, the space of freedom of the judge in deciding the case is not allowed to be unlimited or arbitrarily, but still taking into account the normative aspect.

\section{The Existence of Good Faith in a Court} Decision

The discussion of legal protection for a good faith buyer has provided a clear picture regarding the influence of a court decision in determining a good faith or not good faith in a person. It is a good faith when the position of a good faith obtained from the procedure of ownership right under the Indonesian Civil Code and he does not know there is a legal error in obtaining such ownership right. The problem is how the implementation of sale and purchase with having no good faith such as fraud in which the buyer does not know about it. Article 1328 of Indonesian Civil Code said that fraud constitutes a reason for cancelling the agreement, where the buyer breached the Article 1338 of Indonesian Civil Code regarding good faith, mentioning that an agreement has to be conducted based on justice and appropriateness. The implementation of a good faith definition in an agreement related to the 3 (three) actions of parties in the agreement, such as: ${ }^{32}$

1. Each party has to uphold their promises or statements;

2. Each party is not allowed to take any advantage by way of misleading to one of the party;

3. Each party has to obey their obligation and conducts as a honorable and honest person, although the obligation does not clearly mention under the agreement. This concept is in line with the Article 1339 of Indonesian Civil Code.

Related to fraud, it can be said that the seller is a party who has a bad faith so how about the buyer? Under Article 1341 of Indonesian Civil Code mentioned that, "Nevertheless, every creditor may propose for the nullification of any unobligated action which is done by the debtor under whatever name, which is disadvantageous to the creditor, provided that it can be proved, that when the action is performed, both the debtor and the person for whom may bring disadvantageous to the creditors."

The buyer is a party who has a good faith so that the rights of a good faith acquired by the third party over the goods becoming the nullified action remains protected. ${ }^{33}$ The discussion of theory ideally put the rights protection of a good faith buyer in the first priority, however, in practice, it is often that the court decision with regards to ownership dispute against a good faith buyer ending up the breach of the rights of a good faith buyer, particularly in the sense of a good faith buyer as a third party in a dispute. The legal protection for a good faith buyer should not stop in an applicable legal remedy for recognizing the position of good faith of a person, however, the existence of legal protection feels faster if such protection is aimed for protecting the rights of such a good faith buyer. In practice, a good faith buyer is not necessarily entitled to rights of what should be entitled to from its position, although it is admitted his or her good faith existence. It is very often that a court decision, particularly in the event that a good faith buyer as third party, does not consider the rights that should be protected on a good faith buyer.

It often happens, for instance, $\mathrm{C}$ as a good faith buyer, is entitled for asking returning cost that he spent for B, after the agreement is nullified to B. Another illustration is, $\mathrm{C}$ as the holder of ownership right over such object, he can rebut against the case between $\mathrm{A}$ and $\mathrm{B}$, where in that sense, the judges

Erna Widjajati, "Itikad Baik dalam Jual Beli Tanah di Indonesia”, Al-Qisth Jurnal Ilmiah Hukum, Vol. 11, No. 1, January - June 2010, pp. 89-100. 
can decide that $\mathrm{C}$ is a good faith buyer that should be protected so that the object belongs to $\mathrm{C}$ has to be released from the dispute between $\mathrm{A}$ and $\mathrm{B}$, it becomes the responsibility of $\mathrm{B}$ to $\mathrm{A}$ for replacing in the form of material.

Article 1328 of Indonesian Civil Code said that the fraud is a reason to nullify the agreement, if one of the contracting parties committed fraud, then the fraud must be one of the reasons to nullify the agreement, the nullification will not happen if the contracting parties do not commit any fraud. Such nullification constitutes a null and void of an agreement, so it has to restore the condition like a normal condition before the agreement concluded. However, in practice, the nullification does not necessarily become the solution against the losses suffered by a good faith buyer. For instance, a good faith buyer has already transferred his object to other party, so if the agreement is null and void, it will affect on the compensation from the good faith buyer to the next potential buyer, thus, it may trigger losses for the next potential good faith buyer. So the proper protection for a good faith buyer is in the form of control in natuura.

Based on such illustration, it can be seen that at the end, is the judges who determine which party having a good faith and which not having good faith, and the judges determine as well on what kind of protection granting to a good faith buyer, in the form of compensating damages or in the form of control in natuura. The judges determine both issues, has to take into account the civil law principles and the applicable legal theories. Thus, in this condition, the realism legal theory has a role, the realism legal theory obliges the judges to interpret the Act dynamically in passing the decision ${ }^{34}$, it is not only based on Articles and texts in the Act but also based on the contexts and reality in society, in which the legal realism theory applied as a tool to achieve the decision contained justice, certainty and advantage.

\section{The Legal Protection for a Good Faith Buyer in a Court Decision}

Subekti mentioned that a good faith in the definition as: a good faith is honesty, a good faith person put the trust fully to the opposing party, who is considered to be honest and does not hide any bad issue that in the subsequent event may bring difficulties. ${ }^{35}$ The definition based on Subekti, it may be correct for reflecting on what is meant by a good faith in daily life.

In a legal context, a good faith has psychological elements and ethic. It consists of a trust that a person doing something in line with the law (good-faith belief), whereas a good faith with element of ethic consists of a person behavior is in line with standard of morality (good faith-probity or good faith-honesty). ${ }^{36}$ The good faith with an ethic element is closely related to the honesty and appreciation of promises or declaration under the concluded agreement. Besides, the good faith has a nature of subjectivity that is often related to the law of property as a good faith buyer is an honest person and does not know the defects attached in the object that he bought, whereas a good faith has a nature of objectivity is the standard of good faith refers to the written norms or unwritten norms or legal norms as a source of law in an agreement. ${ }^{37}$ A good faith has 3 functions such as: ${ }^{38}$

a. The function of obliging the agreement has to be interpreted based on good faith, meaning that the agreement has to be interpreted proportionate and reasonable;

b. The function of adding or completing, meaning that a good faith can add the substance or wordings in an agreement if there is right and obligation occurred

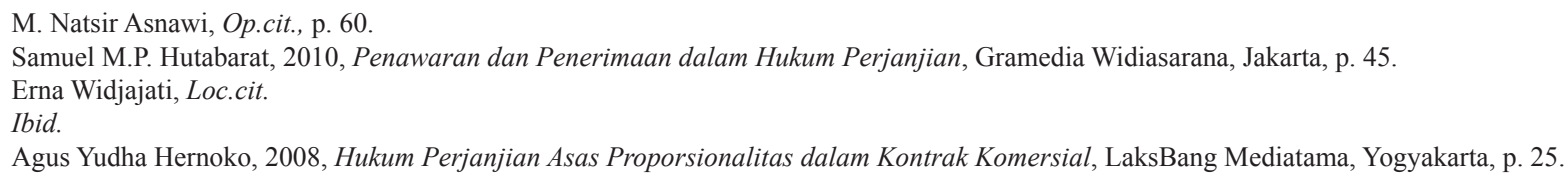


between the contracting parties does not clearly express in the agreement;

c. The function of limiting or removing, meaning that this function is only applicable if there are reasonable interests.

It is often that the problem of a good faith buyer occurred from the lack of knowledge over the status of the object or there is fraud or dishonesty from the seller to the buyer. Such lack of knowledge of the buyer does not necessarily make the buyer having a good faith, the seller who has a bad faith does not necessarily make the buyer having a bad faith as well, as long as it has an element of lack of knowledge and the sale and purchase is considered legal under the applicable law. However, it should bear in mind as stipulated under the Supreme Court Decision of the Republic of Indonesia Number: $1816 \mathrm{~K} / \mathrm{Pdt} / 1989$ on October $22^{\text {nd }}, 1992$ stated that the buyer cannot be classified as a good faith buyer, since the purchasing process is conducted under carelessness of the buyer, when the purchasing process, the buyer does not check the right and status of sellers over the disputed land, thus, such buyer is not entitled to legal protection in such transaction.

The judges have an important role with regards to such issue. Theoretically, it can be said that the buyer remains having a good faith as long as the buyer does not know the defects of objects that the buyer bought, but, for proving such lack of knowledge is not easy. Therefore, it uses the term of "is allegedly" or "should be known" in a court decision for proving the lack of knowledge of a person is not true, so that it can be said as a bad faith buyer. The other way around happens, without understanding any background of the buyer and the relationship with the seller, it is sometimes found the element of intention for transferring the disputed object, the judge protects the interest of buyer by way of saying that a good faith buyer has to be protected by law so it may result to the losses for the plaintiff.

After the bad faith of person is proven so the agreement is null and void. The nullification in legal theory is divided into two: null and void and can be nullified..$^{39}$ It is null and void if the nullification is based on Act. Null and void may result that the legal action will be considered never exist. Whereas, 'can be nullified' means that the agreement will be nullified or not, it is up to the contracting parties. 'Can be nullified' has legal consequence after court decision who nullified such legal action, thus, the legal action will be still applicable until the final decision. ${ }^{40}$

However, a bad faith does not necessarily bring result to a nullification of an agreement. In the condition when the seller does not disclose any defects of an object to the buyer, it cannot be directly declared as a buyer not having a good faith, thus, his rights remains protected by law. In such condition, the buyer cannot be said as a carelessness buyer as stipulated in Precedent of Supreme Court Number 1816K/Pdt/1989 on October 22 2 nd 1992. The carelessness happens when the buyer does not check at first the object that he will buy, whereas, for a fraud, is not a real condition towards the sale purchase object that is showed by the seller to the buyer, thus, the buyer with all his carefulness becomes fooled. In this sense, a buyer remains considered as a good faith buyer protected by the law.

The role of judge, in determining a good faith or not good faith of buyer, is high, the judge has to be able to see the reality, not only in the text under Act where in the sense of realism legal theory has a role. Basically, the legal theory has 3 (three) tasks: first, the legal theories analyses and elaborate the understanding of 'law' and the concept of 'judicial'; second, the legal theory related to the relationship between the law and logic; third, the legal theory

\footnotetext{
39 Nindyo Pramono, "Problematika Putusan Hakim dalam Perkara Pembatalan Perjanjian”, Mimbar Hukum, Vol. 22, No. 2, June 2010, pp. 224233. 
related to the methodology theoretically and practically. ${ }^{41}$ The realism legal theory can be said as a theory elaborating the understanding of law through the concept of its logic in practical methodology.

Considering Holmes theory, saying that the real truth is not in the Act but in reality life and along with that, Jerome Frank, has an idea that a judge can make other decision out of the scenario of regulations; it is more honorable than in the regulation. ${ }^{42}$ The realism legal theory sees the law not only in the context of Act, but also in the context of reality. Therefore, before deciding whether a person havinf a good faith or not, the judge has to be able to see the reality or the relationship between the seller and the buyer.

The wisdom of judge in determining a good faith buyer is highly important and needed. Besides applying the realism legal theory in passing decision, it should be taken into account the factors that influence the court decision itself. There are three main factors influencing the court decisionmaking process: ${ }^{43}$

a. Raw input, the factor that is related to race, religion, informal education and so on.

b. Instrumental input, that is a factor related to the occupation and formal education

c. Environmental input, that is a factor of environment, social-cultural that affects in at life of a judge, like an organizational environment and so on.

Yahya Harahap elaborate such factors in 2 factors: Subjective factor and objective factor. ${ }^{44}$ The subjective factor covers:

a. A priori behavior is an action of judge that is from the beginning the judge is considered that an accused is a person who is guilty and entitled to criminal sanctions. b. Emotional behavior is a court decision will be influenced by the manner of the judges. The Judges who are taking all too seriously (sensitive) will be different with the judge who is less sensitive. It is also different between a court decision made by a judge who is easily being angry and a judge who is patient.

c. Arrogance power is another behavior that influence the court decision is "arbitrary power", the judge feels himself take control and smart, more than the prosecutor, lawyers and accused.

d. Morality is a morality of a judge, all behavior of judges based on their personal morality, particularly in examining cases and passing decision.

Objective factors cover:

a. Social and cultural background, is culture, religion and education influences a decision of judge. Although, the background of culture is not the determinant, but this factor influences the judges in taking decision.

b. Professionalism, is an intelligent and professionalism of the judge influence in decision making process. The difference of a court decision is often influenced by the professionalism of judges.

Such factors may bring result to a dissenting opinion between judges in passing the decision. So that we can find a lot of different decisions for a similar case. As a result of such disparity, between the district court decision and high court decision, at the end it may result to a negative perception coming from public. The negative stigma seems like the judicial system does not have any law standard in examining cases, even there is an idea that the court

\footnotetext{
41 Meuwissen, 2007, Tentang Pengembanan Hukum, Ilmu Hukum, Teori Hukum dan Filsafat Hukum (Trans. Shidarta), Refika Aditama, Bandung, p. 29.

Bernard L. Tanya, et al., Op.cit., p. 151.

3 M. Syamsudin, 2012, Konstruksi Baru Budaya Hukum Hakim Berbasis Hukum Progresif, Kencana Prenada Media Group, Jakarta, p. 93.

44 Antonius Sujata, 2007, Hati Nurani Hakim dan Putusannya, Citra Aditya Bakti, Jakarta, p. 94.
} 
does not have any unification of legal opinion and unified legal framework in examining similar cases.

The basis principle in civil law said that in an agreement that is null and void, the position of contracting parties must be restored, as the agreement does not ever exist. This doctrine teaches us if an agreement is null and void, the consequence is there is no parties suffered damages..$^{45}$ In this event, judge has an important role in making decision. Judge must be careful in making decision of null and void without restoring the condition of parties. The judges is not allowed to fully pay attention to the allegation of claim, in which generally ask the judge to declare a null and void of an agreement with a compensation. A decision may affect to the losses of a party, the judge decision is not clear and careful since the considerations are not based on theory or doctrines in literature. ${ }^{46}$

Besides, the judge should examine which agreement can be nullified and which cannot. The consideration shall be reviewed from its advantages, with taking into account the rights of buyer to be protected by law. Judges become determinants on whether the rights of a good faith buyer are restored with a compensation or to be protected with the control of object in natuura in which our Act does not regulate on how the protection is given to the buyer. The provision said that a good faith buyer is protected by law in Article 548 of Indonesian Civil Code and Article 582 of Indonesian Civil Code. Thus, the implementation of realism legal theory in examining cases regarding good faith can be a guidance in decision making process contained justice, legal certainty and advantage.

\section{Conclusion}

The aim of this paper is not for teaching to everyone but this paper aims to open other point of view for the readers regarding good faith in a court decision. A good faith buyer is a buyer who is protected by law, as stipulated under the Indonesian
Civil Code. The problem of a good faith buyer occurs with the claim from another party who sue the position of a good faith person, thus, the protection for a good faith buyer is closely related to the court whether such buyer having a good faith or not.

A person has a good faith if the good faith is obtained from the procedure of ownership right as regulated in Indonesian Civil Code and there is no legal defects detected in the right of ownership. The question would be how the activity of sale and purchase that is bad faith, for instance, with a fraud, the buyer does not know it. The problem of a good faith coming from the lack of knowledge of buyer towards the status of an object. Such lack of knowledge of a buyer, does not necessarily mean that the seller has a bad faith as long as there is an element of lack of knowledge over the objects and the sale purchase activity is valid under the law.

Theoretically, the buyer having a good faith as long as he does not know the defect of an object, however, to prove that lack of knowledge is not easy. The role of judge is important to decide it. The judge should take a look at the reality, not just in contextual Act. Before determining a good faith person or not, the judge has to see the reality and the relationship between the seller and the buyer.

Besides, the judge should examine which agreement can be nullified and which cannot. Judge must be careful in making decision of null and void without restoring the condition of parties. The consideration shall be reviewed from its advantages, with taking into account the rights of buyer to be protected by law. Judges become determinants on whether the rights of a good faith buyer are restored with a compensation or to be protected with the control of object in natuura in which our Act does not regulate on how the protection is given to the buyer, thus, it needs a better understanding regarding a good faith in practice or in principles in the civil law. 


\section{BIBLIOGRAPHY}

\section{A. Books}

Asnawi, M. Natsir, 2014, Hermeneutika Putusan Hakim: Pendekatan Multidisipliner dalam Memahami Putusan Peradilan Perdata, UII Press, Yogyakarta.

Cahyadi, Antonius and Fernando M. Manulang, 2007, Pengantar ke Filsafat Hukum, Fajar Interpratama, Jakarta.

Fuady, Munir, 2006, Aliran Kritis Paradigma Ketidakberdayaan Hukum, Citra Aditya Bakti, Bandung.

Garner, Bryan A, 2009, Black's Law Dictionary, Thompson Reuters, USA.

Harahap, M. Yahya, 1993 Perlawanan terhadap Eksekusi Grose Akta Serta Putusan Pengadilan dan Arbitrase dan Standar Hukum Eksekusi, Citra Aditya Bakti, Bandung. , 2007, Hukum Acara Perdata: tentang Gugatan, Persidangan, Penyitaan, Pembuktian dan Putusan Pengadilan, Sinar Grafika, Jakarta.

Hernoko, Agus Yudha, 2008, Hukum Perjanjian Asas Proporsionalitas dalam Kontrak Komersial, LaksBang Mediatama, Yogyakarta.

Hutabarat, Samuel M.P., 2010, Penawaran dan Penerimaan dalam Hukum Perjanjian, Gramedia Widiasarana, Jakarta.

Mahkamah Agung RI, 2008, Pedoman Teknis Administrasi dan Teknis Peradilan Perdata Umum dan Perdata Khusus, Buku II, Mahkamah Agung RI, Jakarta.

Marwan, 2004, Pengantar Ilmu Hukum, Ghalia, Jakarta.

Meliala, Djaja S., 1987, Masalah Itikad Baik dalam
KUHPerdata, Binacipta, Bandung.

Mertokusumo, Sudikno, Hukum Acara Perdata Indonesia, Liberty, Yogyakarta. Penemuan Hukum: Sebuah Pengantar, Cahaya Atma Pustaka, Jakarta.

Meuwissen, 2007, Hak tentang Pengembanan Hukum, Ilmu Hukum, Teori Hukum dan Filsafat Hukum (Trans. Shidarta), Refika Aditama, Bandung.

Muhammad, Abdulkadir, 1990, Hukum Acara Perdata Indonesia, Citra Aditya Bakti, Bandung.

Musthofa, Wildan Suyuthi, 2013, Kode Etik Hakim, Kencana, Jakarta.

Sujata, Antonius, 2007, Hati Nurani Hakim dan Putusannya, Citra Aditya Bakti, Jakarta.

Supomo, 1985, Hukum Acara Perdata Pengadilan Negeri, Fasco, Jakarta.

Syahrani, Ridwan, 2004, Rangkuman Intisari Ilmu Hukum, Citra Aditya, Bandung.

Syamsudin, M., 2012, Konstruksi Baru Budaya Hukum Hakim Berbasis Hukum Progresif, Kencana Prenada Media Group, Jakarta.

Tanya, Bernard L., et al., 2013, Teori Hukum: Strategi Tertib Manusia Lintas Ruang dan Generasi, Genta, Yogyakarta.

\section{B. Journal Articles}

Pramono, Nindyo, "Problematika Putusan Hakim dalam Perkara Pembatalan Perjanjian", Mimbar Hukum, Vol. 22. No. 2, June 2010.

Widjajati, Erna, "Itikad Baik dalam Jual Beli Tanah di Indonesia", Al-Qisth Jurnal Ilmiah Hukum, Vol. 11, No. 1, January-June 2010. 